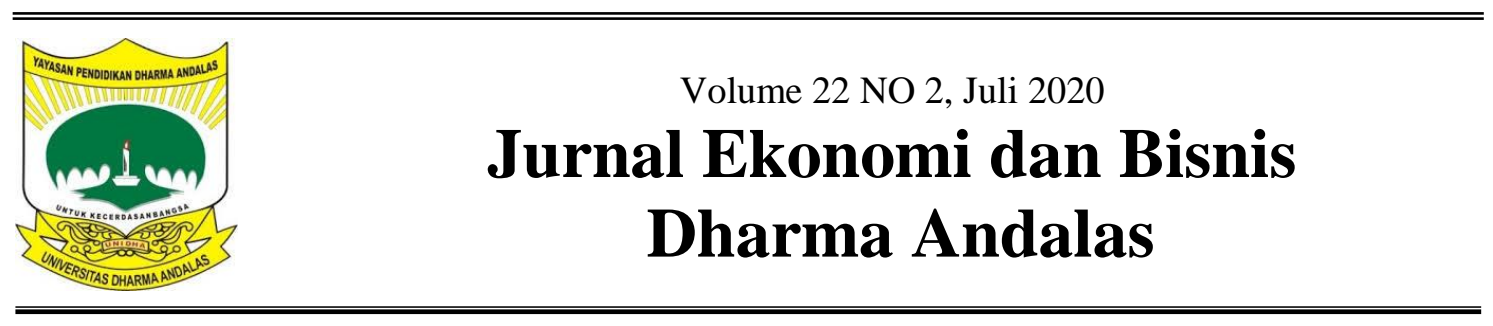

\title{
Analisis Faktor-Faktor yang Mempengaruhi Auditor dalam Memberikan Opini Audit atas Laporan Keuangan Pemerintah Daerah (LKPD) Provinsi Sumatera Barat
}

\author{
Murniati $^{1}$, Widi Natalia ${ }^{2}$ \\ Fakultas Ekonomi Dan Bisnis Universitas Dharma Andalas ${ }^{1,2}$ \\ email: yetmurniati@gmail.com ${ }^{1}$
}

\begin{abstract}
ABSTRAC
This research was conducted to determine the effect of independence, audit expertise, the scope of the audit, audit audit, and interim examination of the consideration of giving audit opinion. In this study, researchers examined the consideration of providing audit opinion at the Office of the Republic of Indonesia Supreme Audit Agency (BPK) of West Sumatra Province by using independent variables, namely independence, audit expertise, audit scope, audit judgment, and interim examination. The population in this study are all auditors who work at the Representative Office of the Supreme Audit Board (BPK) of Republic of Indonesia in West Sumatra Province. The primary data collection method used was a questionnaire method distributed to respondents, the sampling technique was purposive sampling with a sample size of 22 respondents. The results of testing the hypothesis in this study indicate that the variables of independence, audit expertise, audit judgment and interim examination have a positive and significant effect on giving audit opinion, while audit scope variable has no effect but has a negative direction. Simultaneously the variables of independence, audit expertise, audit judgment and interim examination have a positive and significant effect on giving audit opinion.
\end{abstract}

Keywords: audit opinion, independence, audit expertise, audit scope, audit judgment and interim examination.

\begin{abstract}
ABSTRAK
Penelitian ini dilakukan untuk mengetahui pengaruh independensi, keahlian audit, lingkup audit, audit judgemet, dan pemeriksaan interim terhadap pertimbangan pemberian opini audit. Dalam penelitian ini, peneliti mengkaji pertimbangan pemberian opini audit pada Kantor Badan Pemeriksa Keuangan (BPK) RI Perwakilan Provinsi Sumatera Barat dengan menggunakan variabel independen, yaitu independensi, keahlian audit, lingkup audit, audit judgement, dan pemeriksaan interim. Populasi dalam penelitian ini adalah seluruh auditor yang bekerja pada Kantor Perwakilan Badan Pemeriksa Keuangan (BPK) RI Perwakilan Provinsi Sumatera Barat. Metode pengambilan data primer yang digunakan adalah metode kuesioner yang dibagikan kepada responden, teknik pengambilan sampel yaitu dengan purposive sampling dengan jumlah sampel sebanyak 22 responden. Teknik analisis data yang digunakan dalam penelitian ini adalah teknik analisis regresi linier berganda. Hasil dari pengujian hipotesis dalam penelitian ini menunjukkan bahwa variabel independensi, keahlian audit, audit judgement dan pemeriksaan interim berpengaruh positif dan signifikan terhadap pemberian opini audit, sedangkan variabel lingkup audit tidak berpengaruh namun beraarah negatif. Secara simultan variabel independensi, keahlian audit, audit judgement dan pemeriksaan interim berpengaruh positif dan signifikan terhadap pemberian opini audit.
\end{abstract}

Kata kunci: opini audit, independensi, keahlian audit, lingkup audit, audit judgement dan pemeriksaan interim. 


\section{PENDAHULUAN}

Menurut Undang-Undang Dasar 1945, Pasal 23E yaitu tentang Pemeriksaan Pengelolaan dan Tanggung Jawab Keuangan Negara, serta UndangUndang Nomor 15 Tahun 2006 tentang Badan Pemeriksa Keuangan, tugas dan wewenang BPK adalah melakukan pemeriksaan pengelolaan dan tanggung jawab keuangan negara yang dilakukan oleh pemerintah pusat, pemerintah daerah, lembaga negara lainnya, Bank Indonesia, badan usaha milik negara, badan layanan umum, badan usaha milik daerah dan lembaga lainnya yang mengelola keuangan negara, pemeriksaan yang dilakukan BPK berdasarkan atas UndangUndang tentang pemeriksaan pengelolaan dan tanggung jawab keuangan negara, pemeriksaan yang dilakukan BPK mencakup pemeriksaan kinerja, keuangan, dan pemeriksaan dengan adanya tujuan tertentu serta melakukan pembahasan atas temuan pemeriksaan dengan objek yang diperiksasesuai dengan standar pemeriksaan keuangan negara.

Pelaporan keuangan yang disajikan harus memenuhi karakteristik kualitatif, untuk memenuhi karakteristik kualitatif maka informasi yang disajikan oleh laporan keuangan harus disajikan secara wajar berdasarkan Peraturan Pemerintah No. 24 Tahun 2005 tentang Standar Akuntansi Pemerintah, Informasi akuntansi yang terdapat dalam laporan keuangan pemerintah daerah harus memenuhi beberapa karakteristik kualitatif yaitu, Relevan, Lengkap, Andal, Dapat Dibandingkan dan Dapat Dipahami. Oleh karena itu perlu dilakukan pemeriksaan atas laporan keuangan pemerintah daerah yang bertujuan untuk menilai kewajaran laporan keuangan berdasarkan SAP yang berlaku umum di Indonesia.

Auditor BPK setelah melakukan pemeriksaan atas LKPD akan memberikan tanggapan berupa opini namun tidak hanya berupa upa opini yang dihasilkan oleh auditor tetapi juga memberikan catatan hasil temuan.Menurut (Siregar 2012)Opini audit adalah pernyataan profesional sebagai kesimpulan pemeriksa mengenai tingkat kewajaran informasi yang disajikan dalam laporan keuangan.Badan Pemeriksaan Keuangan (BPK) selaku auditor pemerintah dapat memberikan empat jenis opini berdasarkan keputusanBPK RI Nomor4/K/IXIII.2/9/2012 pragraf 13 terhadap laporan pertanggungjawaban yang disajikan oleh pemerintahyaitu Wajar Tanpa Pengecualian (Unqualified Opinion), Wajar dengan Pengecualian (Qualified Opinion), Tidak Wajar (Adverse Opinion), dan Tidak Memberikan Pendapat (Disclaimer Opinion). Opini informasi yang disajikan oleh auditor harusalah mencerminkan keadaan yang sesunguhnya, informasi yang berkualitas hanya bisa diperoleh dari seorang auditor yang berkualitas juga.

Audit Judgement merupakan kebijakan auditor dalam nenetukan pendapat mengenai hasil pemeriksaan yang mengacu pada suatu gagasan pendapat atau pemikiran tentang dustu objek, peristiwa, status atau lainnya. Dalam membuat laporan hasil pemeriksaan seorang auditor harus mempertimbangkan beberapa permasalahan berupa materialitas, risiko dan judgement. Audit judgement dalam penelitian ini diambil berdasarkan pertimbangan pertimbangan auditor, semakin bersar tingkat materialitas semakin cenderung auditor memberikan opini tidak menyatakan pendapat.Dalam memberikan opini, auditor juga memperhatikan tingkat materialitas.

Opini yang diberikan atas laporan keuangan merupakan cerminan bagi kualitas pengelolaan dan penyajian atas laporan keuangan. Belum diperolehnya opini WTP dari BPK menunjukkan bahwa pelaporan keuangan Pemerintah daerah masih belum sepenuhnya dapat diyakini 
kewajarannya oleh BPK yang disebabkan oleh berbagai faktor, diantaranya : terdapat kelemahan sistem pengendalian intern (SPI), penyajian laporan keuangan yang masih belum sesuai dengan Standar Akuntansi Pemerintahan (SAP), terdapat tidak sesuainya pelaksanaan pengadaan barang dan jasa dengan ketentuan yang berlaku, belum tertatanya barang milik negara/daerah dengan tertib, kelemahan dalam sistem penyusunan laporan keuangan serta kurang memadainya kompetensi SDM pengelola keuangan pada pemerintah daerah.

Penelitian ini difokuskan pada Auditor BPK- RI Perwakilan Provinsi Sumatera Barat, Alasan penggunaan populasi ini karena Auditor mempunyai peranan penting dalam hal memberikan opini atas laporan keuangan pemerintah daerah baik dalam penyusunan dan penyampaian laporan keuangan pemerintah. Dapat dilihat Sumatera Barat dinilai berhasil menyusun dan menyajikan laporan keuangan yang berkualitas pada tahun 2016-2018.

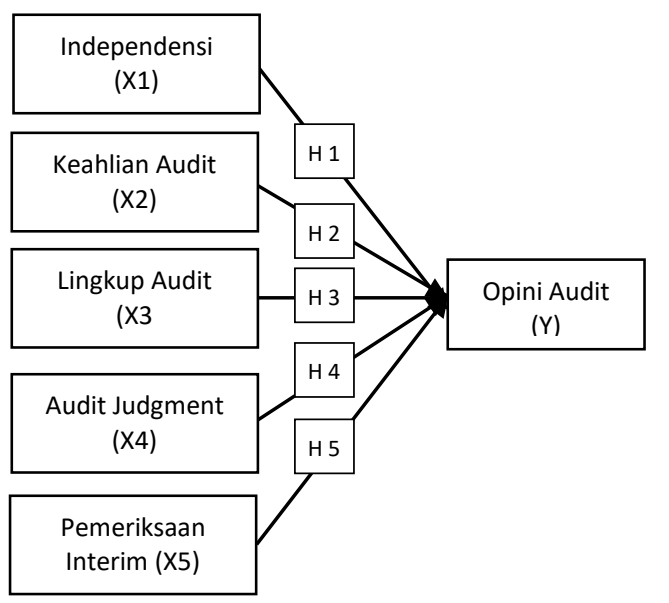

\section{Gambar 1 \\ Kerangka Penelitian}

Hipotesis Penelitian

H1 : Independensi berpengaruh signifikan positif terhadap pemberian opini audit oleh auditor.

H2 : Keahalian audit berpengaruh signifikan positif terhadap pemberian opini audit oleh auditor.
H3 : Lingkup Audit berpengaruh signifikan positif terhadap pemberian opini audit oleh auditor.

H4 : Audit Judgement berpengaruh signifikan positif terhadap pemberian opini audit oleh auditor.

H5 : Pemeriksaan interim berpengaruh signifikan positif terhadap pemberian opini audit oleh auditor

\section{METODE PENELITIAN}

Penelitian ini menggunakan analisis deskriktif dan regresi linear berganda, dilaksanakn di kantor Badan BPK-RI Perwakilan Provinsi Sumatera Barat. Populasi dalam penelitian ini adalah auditor eksternal pemerintah yaitu auditor BPK-RI Perwakilan Provinsi Sumatera Barat Jumlah sampel 22 orang.

Jenis data yang digunakan dalam penelitian ini adalah data primer, Teknik pengumpulan data dalam penelitian ini mengunakan metode survei,

\section{Variabel Penelitian}

Dalam penelitian ini terdapat enam variabel utama yaitu Independensi (X1), Keahlian Audit (X2), Lingkup Audit (X3), Audit Judgement (X4) dan Pemeriksaan Interim (X5) sebagai variabel bebas. Serta Opini Audit (Y) sebagai variabel terikat.

Teknik analisis data data yang digunakan dalam penelitian ini adalah dengan melakukan; (1) Analisis Statistik Deskriktif; (2) Uji Kualitas Data; (3) Uji Validitas; (4) Uji Reliabilitas; (5) Uji Hipotesis

- Untuk menguji ada tidaknya pengaruh independensi, keahlian audit, lingkup audit, audit judgement dan pemeriksaan interim terhadap pemberian opini audit, baik secara simultan maupun secara pasrsial diguakan analisis statistik dengan regresi linier berganda dengan model persamaan regresi sebagai berikut: $Y=\alpha+\beta_{1} X_{1}+\beta_{2} X_{2}+\beta_{3} X_{3}+\beta_{4} X_{4}+\beta_{5} X_{5}$ 
Keterangan :

Y : Opini Audit

A : Konstanta

$\mathrm{X}_{1}$ : Independensi

$\mathrm{X}_{2}$ : Keahlian Audit

$\mathrm{X}_{3}$ : Lingkup Audit

$\mathrm{X}_{4}$ : Audit Judgement

$\mathrm{X}_{5}$ : Pemeriksaan Interim

e : Standar Erorr

\section{HASIL DAN PEMBAHASAN}

Analisis Statistik Deskriptif

Tabel 1 berikut ini merupakan hasil analisis statistik deskriptif

\section{Tabel 1}

Hasil Analisis Statistik Deskriptif

\begin{tabular}{lccccc}
\hline \multicolumn{1}{c}{ Variabel } & $\begin{array}{c}\text { Kisaran } \\
\text { Teoritsi }\end{array}$ & $\begin{array}{c}\text { Rata- } \\
\text { rata } \\
\text { Teoritis }\end{array}$ & $\begin{array}{c}\text { Kisaran } \\
\text { Aktual }\end{array}$ & $\begin{array}{c}\text { Rata- } \\
\text { rata } \\
\text { (Means) }\end{array}$ & $\begin{array}{c}\text { Standar } \\
\text { Deviation }\end{array}$ \\
\hline Independensi & $10-41$ & 26 & $26-41$ & 31,91 & 3,598 \\
$\begin{array}{l}\text { Keahlian } \\
\begin{array}{l}\text { Audit } \\
\text { Lingkup Audit }\end{array}\end{array}$ & $10-50$ & & $36-50$ & 42,23 & 4,429 \\
$\begin{array}{l}\text { Audit } \\
\text { Judgement }\end{array}$ & $5-25$ & 24 & $26-40$ & 31,55 & 3,789 \\
$\begin{array}{l}\text { Pemeriksaan } \\
\text { Interim }\end{array}$ & $5-24$ & 15 & $15-25$ & 20,86 & 2,587 \\
Opini Audit & $12-60$ & 15 & $16-24$ & 20,00 & 2,309 \\
\hline
\end{tabular}

\section{Independensi}

Rata-rata aktual (mean) untuk seluruh responden adalah 31,91 sedangkan rata-rata teoritisnya adalah 26. Karena rata-rata aktual lebih tinggi dari pada rata-rata teoritis, dapat ditarik kesimpulan bahwa auditor BPK memiliki independensi yang tinggi itu artinya auditor berada dalam keadaan bebas, tidak dikendalikan oleh pihak lain dan tidak tergantung pada orang lain dalam melakukan proses pemeriksaan. Standar deviasi untuk variabel independensi menunjukan ukuran variasi data terhadap rata-rata (jarak rata-rata data terhadap mean) dimana standar deviasi variabel independensi sebesar 3,598. Hal ini berarti variansi data lebih relatif kecil karena standar deviasi lebih kecil dari rata-rata.

\section{Keahlian Audit}

Variabel keahlian audit diukur dengan mengunakan instrumen yang terdiri dari 10 pertanyaan. Dapat dilihat pada tabel 1 dari 22 responden dihasilkan rentang aktual 36 sampai dengan 50, artinya tingkat keahlian audit yang kurang berada pada kisaran 36 dan tingkat keahlian audit lebih tinggi berada pada kisaran 50 dan kisaran teoritis 10 sampai dengan 50. Rata-rata aktual (mean) un seluruh responden adalah 42 sedangkan rata-rata teoritisnya adalah 30 . Karena rata-rata aktual lebih tinggi dari pada rata-rata teoritis, dapat ditarik kesimpulan bahwa auditor BPK memiliki keahlian audit yang tinggi itu artinya auditor memiliki keterampilan yang memadai untuk pemeriksaan yang dilakukan, memiliki kemahiran dibidang akuntansi khususnya auditing, serta telah memahami prinsip akuntansi yang berlaku umum di indonesia. Standar deviasi untuk variabel keahlian audit menunjukan ukuran variasi data terhadap rata-rata (jarak rata-rata data terhadap mean) dimana standar deviasi variabel keahlian audit sebesar 4,429. Hal ini berarti variansi data lebih relatif kecil karena standar deviasi lebih kecil dari rata-rata.

\section{Lingkup Audit}

Rata-rata aktual (mean) untuk seluruh responden adalah 31,55 sedangkan rata-rata teoritisnya adalah 24 . Karena rata-rata aktual lebih tinggi dari pada rata-rata teoritis, dapat ditarik kesimpulan bahwa batasan bagi auditor BPK untuk dapat menerapkan prosedur audit, baik ditentukan oleh klien seperti waktu pelaksanaan audit, kegagalan memperoleh bukti, ketidak cupan catatan akuntansi. Standar deviasi untuk variabel lingkup audit menunjukan ukuran variasi data terhadap rata-rata (jarak rata-rata data terhadap mean) dimana standar deviasi variabel keahlian audit sebesar 3,789. Hal ini berarti variansi data lebih relatif kecil karena standar deviasi lebih kecil dari rata-rata.

\section{Audit Judgement}

Rata-rata aktual (mean) untuk seluruh responden adalah 20,86 sedangkan rata-rata teoritisnya adalah 15 . Karena rata-rata aktual lebih tinggi dari 
pada rata-rata teoritis, dapat ditarik kesimpulan bahwa auditor BPK memiliki pertimbangan terhadap tingkat materialitas dan risiko atau termasuk dalam kategori obyektif. Standar deviasi untuk variabel audit judgement menunjukan ukuran variasi data terhadap rata-rata (jarak rata-rata data terhadap mean) dimana standar deviasi variabel audit judgement sebesar 2,587. Hal ini berarti variansi data lebih relatif kecil karena standar deviasi lebih kecil dari rata-rata.

\section{Pemeriksaan Interim}

Rata-rata aktual (mean) untuk seluruh responden adalah 20,00 sedangkan rata-rata teoritisnya adalah 15 . Karena rata-rata auktual lebih tinggi dari pada rata-rata teoritis, dapat ditarik kesimpulan bahwa auditor BPK telah melakukan pemeriksaan pendahuluan sebelum pemeriksaan atas laporan keuangan dilakukan. Standar deviasi untuk variabel pemeriksaan interim menunjukan ukuran variasi data terhadap rata-rata (jarak rata-rata data terhadap mean) dimana standar deviasi variabel pemeriksaan interim sebesar 2,309. Hal ini berarti variansi data lebih relatif kecil karena standar deviasi lebih kecil dari rata-rata.

\section{Opini Audit}

Rata-rata aktual (mean) untuk seluruh responden adalah 51,05 sedangkan rata-rata teoritisnya adalah 36 . Karena rata-rata auktual lebih tinggi dari pada rata-rata teoritis, dapat ditarik kesimpulan bahwa dalam pemberian opini auditor BPK selalu mempertimbangkan segala hal yang berkaitan dengan opini yang akan dikeluarkan terhadap hasil pemeriksaan LKPD nantinya sesuai dengan apa adanya. Standar deviasi untuk variabel opini audit menunjukan ukuran variasi data terhadap rata-rata (jarak ratarata data terhadap mean) dimana standar deviasi variabel opini audit sebesar 5,066.

\section{Uji Kualitas Data}

Secara ringkas hasil uji validitas masing-masing variabel dapat dilihat pada tabel 2

Tabel 2

r-tabel Variabel

\begin{tabular}{cc}
\hline Variabel & $\mathbf{r}_{\text {tabel }}$ \\
\hline Independensi(X1) & 0,432 \\
Keahlian Audit (X2) & 0,432 \\
Lingkup Audit (X3) & 0,432 \\
Audit Judgement (X4) & 0,432 \\
Pemeriksaan Interim (X5) & 0,432 \\
Opini Audit (Y) & 0,432 \\
\hline
\end{tabular}

Berikut adalah rangkuman hasil pengujian validitas untuk masing-masing pertanyaan pada variabel Indepenen si, Keahlian Audit, Lingkup Auidit, Audit Judgement, Pemeriksaan Interim dan opini audit :

Uji Validitas Variabel Independensi (X1)

Tabel 3

Hasil Uji Validitas Variabel Independensi (X1)

\begin{tabular}{ccccc}
\hline $\begin{array}{c}\text { No } \\
\text { Item }\end{array}$ & r-hitung & $\begin{array}{c}\text { r-tabel } \mathbf{5 \%} \\
\mathbf{( 2 2 )}\end{array}$ & Sig. & Kriteria \\
\hline 1 & 0,797 & 0,432 & 0,000 & Valid \\
2 & 0,572 & 0,432 & 0,005 & Valid \\
3 & 0,616 & 0,432 & 0,002 & Valid \\
4 & 0,450 & 0,432 & 0,036 & Valid \\
5 & 0,826 & 0,432 & 0,000 & Valid \\
6 & 0,518 & 0,432 & 0,014 & Valid \\
7 & 0,538 & 0,432 & 0,010 & Valid \\
8 & 0,843 & 0,432 & 0,000 & Valid \\
9 & 0,647 & 0,432 & 0,001 & Valid \\
10 & 0,679 & 0,432 & 0,001 & Valid \\
\hline
\end{tabular}

Berdasarkan uji validitas pada variabel independensi (X1) disimpulkan bahwa semua item pertanyaan sudah didapatkan nilai korelasi product moment pearson yang lebih besar dari 0,432 dan nilai signifikansi kurang dari Cronbach's Alpha $(\alpha) 0,05$. Dengan demikian dapat disimpulkan bahwa semua item pertanyaan pada variabel independensi (X1) valid. 
Uji Validitas Variabel Keahlian Audit (X2)

\section{Tabel 4}

Hasil Uji Validitas Variabel Keahlian Audit (X2)

\begin{tabular}{ccccl}
\hline $\begin{array}{c}\text { No } \\
\text { Item }\end{array}$ & r-hitung & $\begin{array}{c}\text { r-tabel } \\
(\mathbf{2 2})\end{array}$ & Sig. & Kriteria \\
\hline 1 & 0,878 & 0,432 & 0,000 & Valid \\
2 & 0,765 & 0,432 & 0,000 & Valid \\
3 & 0,681 & 0,432 & 0,000 & Valid \\
4 & 0,851 & 0,432 & 0,000 & Valid \\
5 & 0,794 & 0,432 & 0,000 & Valid \\
6 & 0,790 & 0,432 & 0,000 & Valid \\
7 & 0,577 & 0,432 & 0,005 & Valid \\
8 & 0,791 & 0,432 & 0,000 & Valid \\
9 & 0,609 & 0,432 & 0,003 & Valid \\
10 & 0,894 & 0,432 & 0,000 & Valid \\
\hline
\end{tabular}

Berdasarkan uji validitas pada variabel keahlian audit (X2) disimpulkan bahwa semua item pertanyaan sudah didapatkan nilai korelasi product moment pearson yang lebih besar dari 0,432 dan nilai signifikansi kurang dari Cronbach's Alpha $(\alpha)$ 0,05. Dengan demikian dapat disimpulkan bahwa semua item pertanyaan pada variabel keahlian audit (X2) valid.

Uji Validitas Variabel Lingkup Audit (X3)

\section{Tabel 5}

\section{Hasil Uji Validitas Variabel Lingkup} Audit (X3)

\begin{tabular}{lllll}
\hline $\begin{array}{c}\text { No } \\
\text { Item }\end{array}$ & r-hitung & $\begin{array}{c}\text { r-tabel } \\
(\mathbf{2 2})\end{array}$ & \multicolumn{1}{c}{ Sig. } & Kriteria \\
\hline 1 & 0,579 & 0,432 & 0,005 & Valid \\
2 & 0,726 & 0,432 & 0,000 & Valid \\
3 & 0,340 & 0,432 & 0,121 & Tidak Valid \\
4 & 0,338 & 0,432 & 0,124 & Tidak Valid \\
5 & 0,624 & 0,432 & 0,002 & Valid \\
6 & 0,473 & 0,432 & 0,026 & Valid \\
7 & 0,757 & 0,432 & 0,000 & Valid \\
8 & 0,757 & 0,432 & 0,000 & Valid \\
\hline
\end{tabular}

Berdasarkan uji validitas pada variabel lingkup audit dapat dilihat pada tabel 5 terdapat dua item pertanyaan yang tidak valid, suatu item pertanyaan dapat dikatkan valid jika nilai $r_{\text {hitung }}>r_{\text {tabel }}$ dan sebaliknya jika nilai $r_{\text {hitung }}<r_{\text {tabel }}$ item pertanyaan tersebut dinyatakan tidak valid. Untuk item pertanyaan kuesioner yang tidak valid peneliti melakukan drop (membuang) item pertanyaan angket yang tidak valid. Kemungkinan penyebab tidak valid adalah jawaban responden yang tidak konsisten, jawban yang tidak konsisten bisa jadi karena pernyataan yang kurang jelas. Berikut hasil pengujian validitas variabel lingkup audit setelah dilakukan drop pada item pertanyaan yang tidak valid dapat dilihat pada tabel 5

Tabel 6

Hasil Uji Validitas Variabel Lingkup Audit (X3)

\begin{tabular}{lllll}
\hline $\begin{array}{c}\text { No } \\
\text { Item }\end{array}$ & \multicolumn{1}{c}{ r-hitung } & $\begin{array}{c}\mathbf{r}_{\text {-tabel }} \mathbf{5 \%} \\
(\mathbf{2 2})\end{array}$ & Sig. & Kriteria \\
\hline 1 & 0,579 & 0,432 & 0,005 & Valid \\
2 & 0,726 & 0,432 & 0,000 & Valid \\
3 & 0,624 & 0,432 & 0,002 & Valid \\
4 & 0,473 & 0,432 & 0,026 & Valid \\
5 & 0,757 & 0,432 & 0,000 & Valid \\
6 & 0,757 & 0,432 & 0,000 & Valid \\
\hline
\end{tabular}

Berdasarkan uji validitas setelah dilakukan drop pada variabel Lingkup Audit (X3) yang tidak valid disimpulkan bahwa semua item pertanyaan sudah didapatkan nilai korelasi product moment pearson yang lebih besar dari 0,432 dan nilai signifikansi kurang dari Cronbach's Alpha $(\alpha)$ 0,05. Dengan demikian dapat disimpulkan bahwa semua item pertanyaan pada variabel lingkup audit (X3) valid.

Uji Validitas Variabel Audit Judgement (X4)

\section{Tabel 7}

Hasil Uji Validitas Variabel Audit Judgement (X4)

\begin{tabular}{lllll}
\hline $\begin{array}{c}\text { No } \\
\text { Item }\end{array}$ & r-hitung & $\begin{array}{c}\text { r-tabel } \\
(\mathbf{2 2})\end{array}$ & Sig. & Kriteria \\
\hline 1 & 0,849 & 0,432 & 0,000 & Valid \\
2 & 0,844 & 0,432 & 0,000 & Valid \\
3 & 0,906 & 0,432 & 0,000 & Valid \\
4 & 0,897 & 0,432 & 0,000 & Valid \\
5 & 0,705 & 0,432 & 0,000 & Valid \\
\hline
\end{tabular}

Berdasarkan uji validitas pada variabel Audit Judgement (X4) 
disimpulkan bahwa semua item pertanyaan sudah didapatkan nilai korelasi product moment pearson yang lebih besar dari 0,432 dan nilai signifikansi kurang dari Cronbach's Alpha $(\alpha)$ 0,05. Dengan demikian dapat disimpulkan bahwa semua item pertanyaan pada variabel Audit Judgement (X4) valid.

Uji Validitas Variabel Pemeriksaan $\operatorname{Interim}(\mathrm{X} 5)$

Tabel 8

Hasil Uji Validitas Variabel Pemeriksaan Interim(X5)

\begin{tabular}{lllll}
\hline $\begin{array}{c}\text { No } \\
\text { Item }\end{array}$ & $\mathbf{r}_{\text {-hitung }}$ & $\begin{array}{c}\mathbf{r}_{\text {-tabel }} \mathbf{5 \%} \\
\mathbf{( 2 2 )}\end{array}$ & Sig. & Kriteria \\
\hline 1 & 0,734 & 0,432 & 0,000 & Valid \\
2 & 0,645 & 0,432 & 0,001 & Valid \\
3 & 0,346 & 0,432 & 0,115 & Tidak Valid \\
4 & 0,647 & 0,432 & 0,001 & Valid \\
5 & 0,709 & 0,432 & 0,000 & Valid \\
\hline
\end{tabular}

Berdasarkan uji validitas pada variabel pemeriksaan interim dapat dilihat pada tabel 8 terdapat satu item pertanyaan yang tidak valid, suatu item pertanyaan dapat dikatkan valid jika nilai $r_{\text {hitung }}>r_{\text {tabel }}$ dan sebaliknya jika nilai $r_{\text {hitung }}<r_{\text {tabel }}$ item pertanyaan tersebut dinyatakan tidak valid.. Berikut hasil pengujian validitas variabel lingkup audit setelah dilakukan drop pada item pertanyaan yang tidak valid dapat dilihat pada tabel 9

\section{Tabel 9}

Hasil Uji Validitas Variabel Pemeriksaan Interim(X5)

\begin{tabular}{lllll}
\hline $\begin{array}{c}\text { No } \\
\text { Item }\end{array}$ & r-hitung & $\begin{array}{c}\text { r-tabel } \mathbf{5 \%} \\
\mathbf{( 2 2 )}\end{array}$ & Sig. & Kriteria \\
\hline 1 & 0,723 & 0,432 & 0,000 & Valid \\
2 & 0,629 & 0,432 & 0,002 & Valid \\
3 & 0,647 & 0,432 & 0,001 & Valid \\
4 & 0,709 & 0,432 & 0,000 & Valid \\
\hline
\end{tabular}

Berdasarkan uji validitas setelah melakukan drop pada variabel pemeriksaan interim (X5) yang tidak valid dapat disimpulkan bahwa semua item pertanyaan sudah didapatkan nilai korelasi product moment pearson yang lebih besar dari 0,432 dan nilai signifikansi kurang dari Cronbach's Alpha $(\alpha)$ 0,05. Dengan demikian dapat disimpulkan bahwa semua item pertanyaan pada variabel pemeriksaan interim (X5) valid.

Uji Validitas Variabel Opini Audit (Y) Tabel 10

Hasil Uji Validitas Variabel Opini Audit (Y)

\begin{tabular}{lllll}
\hline $\begin{array}{c}\text { No } \\
\text { Item }\end{array}$ & r-hitung & $\begin{array}{c}\text { r-tabel } \mathbf{5 \%} \\
(\mathbf{2 2})\end{array}$ & Sig. & Kriteria \\
\hline 1 & 0,875 & 0,432 & 0,000 & Valid \\
2 & 0,909 & 0,432 & 0,000 & Valid \\
3 & 0,909 & 0,432 & 0,000 & Valid \\
4 & 0,796 & 0,432 & 0,000 & Valid \\
5 & 0,833 & 0,432 & 0,000 & Valid \\
6 & 0,542 & 0,432 & 0,009 & Valid \\
7 & 0,796 & 0,432 & 0,000 & Valid \\
8 & 0,322 & 0,432 & 0,144 & Tidak Valid \\
9 & 0,645 & 0,432 & 0,001 & Valid \\
10 & 0,802 & 0,432 & 0,000 & Valid \\
11 & 0,872 & 0,432 & 0,000 & Valid \\
12 & 0,842 & 0,432 & 0,000 & Valid \\
\hline
\end{tabular}

Berdasarkan uji validitas pada variabel opini audit dapat dilihat pada tabel 10 terdapat satu item pertanyaan yang tidak valid, suatu item pertanyaan dapat dikatkan valid jika nilai $r_{\text {hitung }}>r_{\text {tabel }}$ dan sebaliknya jika nilai $r_{\text {hitung }}<r_{\text {tabel }}$ item pertanyaan tersebut dinyatakan tidak valid. Untuk item pertanyaan kuesioner yang tidak valid peneliti melakukan drop (membuang) item pertanyaan angket yang tidak valid. Kemungkinan penyebab tidak valid adalah jawaban responden yang tidak konsisten, jawban yang tidak konsisten bisa jadi karena pernyataan yang kurang jelas. Berikut hasil pengujian validitas variabel lingkup audit setelah dilakukan drop pada item pertanyaan yang tidak valid dapat dilihat pada tabel 11

Tabel 11

Hasil Uji Validitas Variabel Opini Audit (Y)

\begin{tabular}{lllll}
\hline $\begin{array}{c}\text { No } \\
\text { Item }\end{array}$ & r-hitung & $\begin{array}{c}\text { r-tabel } \\
(\mathbf{2 2})\end{array}$ & Sig. & Kriteria \\
\hline 1 & 0,875 & 0,432 & 0,000 & Valid \\
2 & 0,909 & 0,432 & 0,000 & Valid \\
3 & 0,909 & 0,432 & 0,000 & Valid \\
4 & 0,796 & 0,432 & 0,000 & Valid
\end{tabular}




\begin{tabular}{lllll}
\hline $\begin{array}{c}\text { No } \\
\text { Item }\end{array}$ & r-hitung & $\begin{array}{c}\text { r-tabel } \\
(\mathbf{2 2})\end{array}$ & Sig. & Kriteria \\
\hline 5 & 0,833 & 0,432 & 0,000 & Valid \\
6 & 0,542 & 0,432 & 0,009 & Valid \\
7 & 0,796 & 0,432 & 0,000 & Valid \\
8 & 0,645 & 0,432 & 0,001 & Valid \\
9 & 0,802 & 0,432 & 0,000 & Valid \\
10 & 0,872 & 0,432 & 0,000 & Valid \\
11 & 0,842 & 0,432 & 0,000 & Valid \\
\hline
\end{tabular}

Berdasarkan uji validitas pada variabel opini audit (Y) yang telah dilakukan drop disimpulkan bahwa semua item pertanyaan sudah didapatkan nilai korelasi product moment pearson yang lebih besar dari 0,432 dan nilai signifikansi kurang dari Cronbach's Alpha $(\alpha)$ 0,05. Dengan demikian dapat disimpulkan bahwa semua item pertanyaan pada variabel opini audit (Y)valid.

\section{Uji Reliabilitas}

Tabel 12

Hasil Uji Reliabilitas

\begin{tabular}{lccc}
\hline \multicolumn{1}{c}{ Variabel } & $\begin{array}{c}\text { Cronbach's } \\
\text { Alpha }\end{array}$ & $\begin{array}{c}\text { Nilai } \\
\text { Kritis }\end{array}$ & Keterangan \\
\hline Independensi & 0,835 & 0,6 & Reliabel \\
Keahlian Audit & 0,893 & 0,6 & Reliabel \\
Lingkup Audit & 0,715 & 0,6 & Reliabel \\
Audit Judgement & 0,888 & 0,6 & Reliabel \\
Pemeriksaan Interim & 0,655 & 0,6 & Reliabel \\
Opini Audit & 0,931 & 0,6 & Reliabel \\
\hline \multicolumn{1}{c}{. }
\end{tabular}

Berdasarkan pada hasil uji reliabilitas masing-masing variabel penelitian diketahui bahwa nilai cronbach alpha semua variabel lebih besar dari 0,6, sehingga dapat disimpulkan kuesioner pada masing-masing variabel penelitian dapat dikategorikan handal dan dipercaya sebagai alat ukur yang menghasilkan jawaban yang relatif konsisten.

\section{Pengujian Hipotesis}

Untuk dapat menjawab hipotesis, dilakukan analisis regresi linear berganda dengan independensi (X1), keahlian audit (X2), lingkup audit (X3), audit Judgement (X4), pemeriksaan interim (X5) sebagai variabel independensi dan opini audit (Y) sebagai variabel dependen.

\section{Uji Asumsi Klasik}

Uji normalitas bertujuan untuk mengetahui apakah nilai residual berdistribusi normal atau tidak dimana model regresi yang baik adalah yang memiliki nilai residual yang berdistribusi normal.

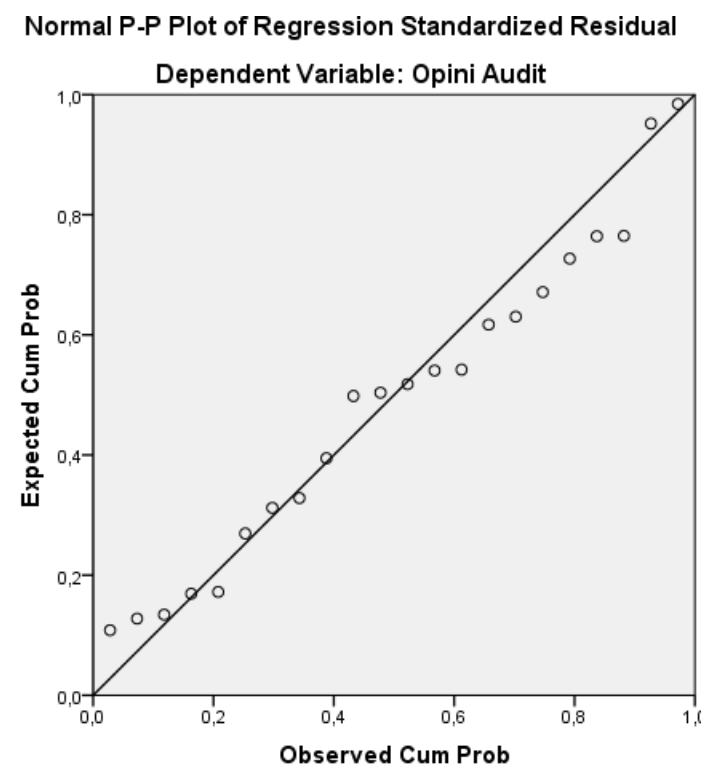

Gambar 1

Grafik Normal P-P Plot

Berdasarkan gambar grafik normal P-P Plot diatas dapat dilihat bawa titiktitik menyimpan dan menyebar disekitar garis diagonal dan mengikuti garis diagonal, maka hasil uji normalitas dapat disimpulkan bahwa nilai residual berdistribusi normal.

\section{Uji Multikolinearitas}

Tabel 13

Hasil Uji Multikolinearitas

\begin{tabular}{lcc}
\hline \multicolumn{1}{c}{ Variabel } & Tolerance & VIF \\
\hline Independensi & 0,937 & 1,067 \\
Keahlian Audit & 0,688 & 1,453 \\
Lingkup Audit & 0,861 & 1,161 \\
Audit Judgement & 0,425 & 2,354 \\
Pemeriksaan Interim & 0,569 & 1,757 \\
\hline
\end{tabular}

Dari hasil pengujian multikolineratitas di atas, diketahui bahwa untuk semua variabel independen dalam penelitian ini menunjukan nilai nilai Tolerance lebih besar dari 0,10 demikian juga dengan nilai Variance Inflantion 
Factor semuanya lebih kecil dari 10 . Dengan demikian dapat disimpulkan bahwa model regresi dalam penelitian ini tidak menindikasikan adanya multikolinearitas atau asumsi non multikolineratitas terpenuhi.

\section{Uji Heteroskedastisitas}

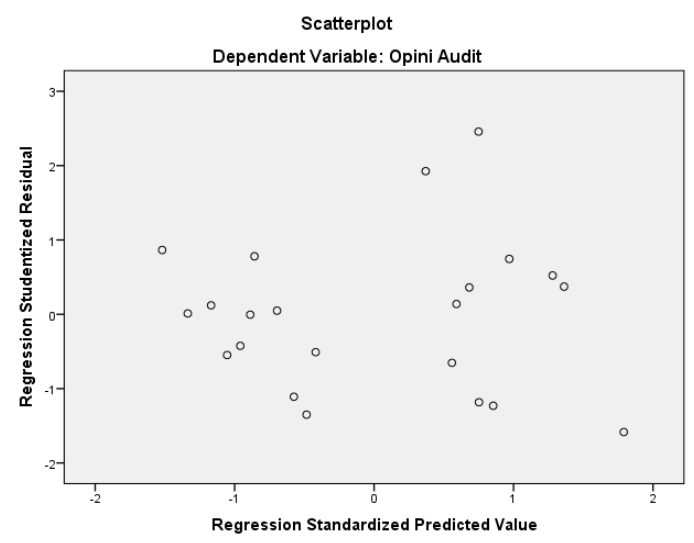

Gambar 3

Scatterplot ZPRED Dan SRESID

Berdasarkan output scatterplots diaatas menunjukan titik-titik data penyebaran diatas dan dibawah atau disekitar angka 0 pada sumbu Y, titik-titik tidak mengumpul hanya di atas atau di bawah saja, penyebaran titik-titik data tidak membentuk pola. Dengan demikian dapat disimpulkan bahwa tidak terjadi masalah heteroskedastisitas, hingga model regresi yang baik dan ideal dapat terpenuhi.

\section{Analisis Regresi Linear Berganda}

\section{Tabel 14}

Hasil Pengujian Regresi

\begin{tabular}{lcccc}
\hline \multicolumn{1}{c}{ Variabel } & Koefisien & $\mathbf{T}_{\text {hitung }}$ & $\mathbf{T}_{\text {tabel }}$ & Sig. T \\
\hline Konstanta & $-1,430$ & & & \\
Independensi & 0,364 & 2,260 & & 0,038 \\
$\begin{array}{l}\text { Keahlian } \\
\text { Audit }\end{array}$ & 0,373 & 2,442 & & 0,027 \\
Lingkup Audit & $-0,307$ & $-1,924$ & 2.120 & 0,072 \\
Audit & 0,878 & 2,641 & & 0,018 \\
Judgement & & & & \\
Pemeriksaan & 0,829 & 2,393 & & 0,029 \\
Interim & & & & \\
\hline R & & & 0,897 & \\
R Square & & & 0,804 & \\
F & & 13,113 & \\
Sig.F & & 0,000 & \\
\hline
\end{tabular}

Tabel 14 memberikan informasi tentang persamaan regresi dan ada tidaknya pengaruh variabel independen terhadap variabel dependen, dari tabel 17 diperoleh rumus regresi dalam penelitian ini sebagai berikut:

$\mathrm{Y}=-1,430+0,364 \mathrm{X}_{1}+0,373 \mathrm{X}_{2}+0,307$

$$
X_{3}+0,878 X_{4}+0,829 X_{5}
$$

\section{Uji Koefisien Determinasi $\left(R^{2}\right)$}

Berdasarkan tabel output model summary pada tabel 14, diketahui nilai koefisien determinasi ( $\mathrm{R}$ Squareatau R Kuadrat) atau disimbolkan dengan $\mathrm{R}^{2}$ sebesar 0,804 atau sama dengan berarti $80,40 \%$. Angka tersebut mengandung arti bahwa variabel independensi (X1), keahlian audit (X1), lingkup audit (X3), audit judgement (X4) dan pemeriksaan interim (X5) secara simultan (bersamasama) berpengaruh terhadap variabel opini audit (Y) sebesar 80,40\%. Sedangkan sisanya sebesar 19,40 \% dipengaruhi oleh variabel lain diluar regresi atau variabel yang tidak diteliti.

\section{Uji Signifikan Simultan (Uji F)}

Berdasarkan tabel ouput SPSS yang telah disajikan pada tabel 14 dimana hasil pengujian terhadap uji signifikansi simultan atau uji $\mathrm{F}$, diketahui nilai $\mathrm{F}_{\text {hitung }}$ 13,113 dengan nilai signifikansi $0,000<$ tingkat signifikan $\alpha 0,05$, maka sesuai dengan dasar pengambilan keputusan dalam uji $\mathrm{F}$ dapat disimpulkan bahwa independensi (X1), keahlian audit (X2), lingkup audit (X3), audit judgement (X4), dan pemeriksaan interim (X5) secara simultan (bersama) berpengaruh terhadap opini audit (Y).

Secara lebih jelas dasar pengambilan keputusan uji $\mathrm{F}$, nilai $\mathrm{F}_{\text {hitung }}$ dibandingkan dengan $F_{\text {tabel }}$ dimana jika $F_{\text {hitung }}>F_{\text {tabel }}$, maka dapat disimpulkan bahwa secara simultan variabel-variabel independen berpengaruh signifikan terhadap variabel dependen. Pada taraf $\alpha$ 0,05 dengan derajatkebebasan pembilang df $_{1} 5$ dan derajat kebebasan penyebut adalah atau $\mathrm{df}_{2}$ (n-k) 17 , diperoleh nilai $F_{\text {tabel }}$ sebesar 2,810 dengan demikian nilai 
$F_{\text {hitung }} 13,113$ lebih besar dari nilai $\mathrm{F}_{\text {tabel, }}$, maka sebagaimana dasar pengambilan keputusan uji $\mathrm{F}$ dapat disimpulkan bahwa independensi (X1), keahlian audit (X2), lingkup audit (X3), audit judgement (X4), dan pemeriksaan interim (X5) secara simultan (bersama) berpengaruh terhadap opini audit (Y).

\section{Uji Parsial (Uji T)}

Hasil dari pengujian hipotesisi pertama $\left(\mathrm{H}_{1}\right)$ yang dijabarkan dalam tabel 14. Tabel tersebut menunjukan bahwa nilai $t_{\text {hitungsebesar }} 2,260$ dengan signifikansi sebesar 0,038. Nilai signifikan untuk variabel independensi menunjukan nilai dibawah tingkat signifikan sebesar 0,005 dan nilai $t_{\text {hitungsebesar } 2,260>\text { dari nilai } t_{\text {tabel }} \text { sebesar }}$ 2,120 yang artinya bahwa $\mathbf{H}_{1}$ diterima atau terdapat adanya pengaruh independensi terhadap pertimbangan pemberian opini audit.

\section{Keahlian Audit}

Hasil dari pengujian hipotesisi kedua $\left(\mathrm{H}_{2}\right)$ yang dijabarkan dalam tabel 14. Tabel 14 tersebut menunjukan nilai thitung sebesar 2,442 dengan signifikansi sebesar 0,027 . Nilai ini signifikan untuk variabel keahlian audit menunjukan nilai dibawah tingkat signifikan sebesar 0,005 dan nilai $t_{\text {hitungsebesar 2,442> dari nilai } t_{\text {tabel }} \text { sebesar }}$ 2,120 yang artinya bahwa $\mathbf{H}_{2}$ diterima atau terdapat adanya pengaruh keahlian audit terhadap pertimbangan pemberian opini audit.

\section{Lingkup Audit}

Hasil dari pengujian hipotesisi ketiga $\left(\mathrm{H}_{3}\right)$ yang dijabarkan dalam tabel 14. Tabel tersebut menunjukan bahwa lingkup audit memiliki nilai signifikansi 0,072 yang berarti lebih besar dari 0,005. Hal ini membuktikan bahwa lingkup audit tidak mempengaruhi secara signifikan terhadap opini audit. Nilai thitung untuk variabel ini sebesar -1,924, nilai ini menunjukan nilai yang negatif sehingga lingkup audit memperngaruhi atas pertimbangan pemberian opini audit secara negatif dan signifikan, jadi dapat disimpulkan hipotesis ke tiga $\left(\mathrm{H}_{3}\right)$ dalam penelitian ini ditolak atau tidak adanya pengaruh lingkup audit terhadap pertimbangan pemberian opini audit.

\section{Audit Judgement}

Hasil dari pengujian hipotesisi keempat $\left(\mathrm{H}_{4}\right)$ yang dijabarkan dalam tabel 14. Tabel tersebut menunjukan bahwa nilai $t_{\text {hitung }}$ sebesar 2,641 dengan signifikansi sebesar 0,018. Nilai signifikan untuk variabel audit judgement menunjukan nilai dibawah tingkat signifikan sebesar 0,005 dan nilai thitung sebesar 2,641> dari nilai tabel sebesar 2,120 yang artinya bahwa $\mathbf{H}_{\mathbf{4}}$ diterima atau terdapat adanya pengaruh audit judgement terhadap pertimbangan pemberian opini audit.

\section{Pemeriksaan Interim}

Hasil dari pengujian hipotesisi kelima $\left(\mathrm{H}_{5}\right)$ yang dijabarkan dalam tabel 14. Tabel tersebut menunjukan bahwa nilai $t_{\text {hitung }}$ sebesar 2,393 dengan signifikansi sebesar 0,029. Nilai signifikan untuk variabel pemeriksaan interim menunjukan nilai dibawahtingkat signifikan sebesar

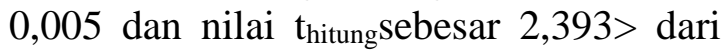
nilai $t_{\text {tabel }}$ sebesar 2,120 yang artinya bahwa $\mathbf{H}_{5}$ diterima atau adanya pengaruh pemeriksaan interim terhadap pertimbangan pemberian opini audit.

\section{Hasil Pengujian Hipotesis}

\section{Pengaruh Independensi terhadap Pemberian Opini Audit oleh Auditor}

Hipotesis pertama menyatakan bahwa independensi berpengaruh signifikan positif terhadap pemberian opini audit oleh auditor. Hasil pengujian statistik untuk $\mathrm{H}_{1}$ secara parsial menunjukan bahwa nilai koesfisien regresi variabel independensi adalah 0,364 nilai ini signifikan pada pada tingkat signifikan 0,005 dengan $p$ value 0,038. Hasil ini didukung oleh hasil perhitungan nilai $t_{\text {thitung }} 2,260>t_{\text {tabel }} 2,120$. Hal ini menunjukan bahwa berdasarkan persepsi auditor pemerintah, independensi berpengaruh signifikan terhadap pertimbangan pemberian opini audit. 
Pengaruh Keahlian Audit terhadap Pemberian Opini Audit oleh Auditor

Hipotesis kedua menyatakan
bahwa keahlian audit berpengaruh
signifikan positif terhadap pemberian
opini audit oleh auditor. Hasil pengujian
statistik untuk $\mathrm{H}_{2}$ secara parsial
menunjukan bahwa nilai koesfisien
regresi variabel keahlian audit adalah
0,373 nilai ini signifikan pada pada
tingkat signifikan 0,005 dengan $p$ value
0,027 . Hasil ini didukung oleh hasil
perhitungan nilai thitung $2,442>$ tabel $2,120$.
Hal ini menunjukan bahwa berdasarkan
persepsi auditor pemerintah, keahlian
audit berpengaruh signifikan terhadap
pertimbangan pemberian opini audit.

Pengaruh Lingkup Audit terhadap Pemberian Opini Audit oleh Auditor

Hipotesis ketiga menyatakan
bahwa lingkup audit berpengaruh signifikan positif terhadap pemberian opini audit oleh auditor. Hasil pengujian statistik untuk $\mathrm{H}_{3}$ secara parsial menunjukan bahwa nilai koesfisien regresi variabel lingkup audit adalah 0,307 nilai ini tidak signifikan pada tingkat signifikan 0,005 dengan $p$ value 0,072. Hasil ini didukung oleh hasil perhitungan nilai $t_{\text {hitung }}-1,924<t_{\text {tabel }} 2,120$, ini menunjukan bahwa berdasarkan persepsi auditor pemerintah, lingkup audit berpengaruh negatif signifikan terhadap pertimbangan pemberian opini audit.

Pengaruh Audit Judgement terhadap Pemberian Opini Audit oleh Auditor

Hipotesis empat menyatakan bahwa audit judgement berpengaruh signifikan positif terhadap pemberian opini audit oleh auditor. Hasil pengujian statistik untuk $\mathrm{H}_{4}$ secara parsial menunjukan bahwa nilai koesfisien regresi variabel audit judgement adalah 0,878 nilai ini signifikan pada pada tingkat signifikan 0,005 dengan $p$ value 0,018 . Hasil ini didukung oleh hasil perhitungan nilai $t_{\text {hitung }} 2,641>\mathrm{t}_{\text {tabel }} 2,120$. Hal ini menunjukan bahwa berdasarkan persepsi auditor pemerintah, audit judgement berpengaruh signifikan terhadap pertimbangan pemberian opini audit.

\section{Pengaruh Pemeriksaan Interim terhadap Pemberian Opini Audit oleh Auditor}

Hipotesis kelima menyatakan bahwa pemeriksaan interim berpengaruh signifikan positif terhadap pemberian opini audit oleh auditor. Hasil pengujian statistik untuk $\mathrm{H}_{5}$ secara parsial menunjukan bahwa nilai koesfisien regresi variabel pemeriksaan interim adalah 0,829 nilai ini signifikan pada tingkat signifikan 0,005 dengan $p$ value 0,029. Hasil ini didukung oleh hasil perhitungan nilai $t_{\text {hitung }} 2,393>t_{\text {tabel }} 2,120$. Hal ini menunjukan bahwa berdasarkan persepsi auditor pemerintah, pemeriksaan interim berpengaruh signifikan terhadap pertimbangan pemberian opini audit. Berdasarkan hasil pengujian statistik deskriktif dapat disimpulkan BPK-RI Perwakilan Provinsi Sumatera Barat telah melakukan pemeriksaan pendahuluan sebelum pemeriksaan atas laporan keuangan dilakukan.

\section{SIMPULAN}

Berdasarkan hasil penelitian, dapat disimpulkan beberapa hal sebagai berikut:

1. Independensi berpengaruh signifikan positif terhadap pemberian opini audit oleh auditor. Hal ini menunjukkan bahwa semakin tinggi independensi seorang auditor, dapat mempermudah auditor dalam mempertimbangkan pemberian opini dibandingkan dengan auditor yang kurang memiliki independensi.

2. Keahlian Audit berpengaruh signifikan terhadap pemberian opini audit oleh auditor. Auditor yang memiliki keahlian yang tinggi akan menghasilkan opini yang baik.

3. Lingkup audit tidak berpengaruh dan berarah negatif terhadap pertimbangan pemberian opini audit oleh auditor. Hal ini menunjukkan bahwa dengan tidak 
adanya pembatasan lingkup audit maka pertimbangan opini auditor pemerintah akan lebih mudah dilakukan dibandingkan dengan adanya pembatasan lingkup audit.

4. Audit Judgement berpengaruh singnifikan positif terhadap pemberian opini audit oleh auditor. Hasil penelitian ini memberikan bukti bahwa pertimbangan auditor dalam menanggapi informasi yang ada akan mempengaruhi opini akhir dalam suatu pelaporan audit, diharapkan sebagai dasar atau acuan bagi Badan Pemeriksa Keuangan untuk meningkatkan kualitas audit judgement yang juga berdampak semakin baiknya hasil dari pemeriksaan.

5. Pemeriksaan interim berpengaruh signifikan positif terhadap pemberian opini audit oleh auditor. Hal ini menunjukkan bahwa dengan adanya pemeriksaan interim maka pertimbangan opini auditor pemerintah akan lebih mudah dilakukan dibandingkan dengan tidak dilakukannya pemeriksaan

Keterbatasan Penelitian

Metode pengumpulan data dengan metode survey oneline melalui kuesioner Google From peneliti memiliki kesulitan mengirim link kuesioner melalui perantara bagian Humas BPK RI perwakilan Provinsi Sumatera Barat dan ditambah auditor pada saat itu disibukan dengan persiapan penyerahan Laporan Hasil Pemeriksaan (LHP), sehingga terdapat banyak responden yang tidak berkenan mengisi atau menjawab kuesioner yang telah disebarkan terlihat dari jumlah auditor yang bekerja di BPK RI Perwakilan Provinsi Sumatera Barat sebanyak 93 orang data yang dapat diolah hanya 22, sisanya tidak diisi.

Pada penelitian ini masih terbatas pada objek penelitian yaitu BPK-RI Perwakilan Provinsi Sumatera Barat saja, sehingga belum tergeneralisasi secara baik, dan hanya bisa digunakan untuk lingkup BPK-RI Perwakilan Provinsi Sumatera Barat saja.

\section{DAFTAR PUSTAKA}

Adrian, Arfin. 2013. "Pengaruh Skeptisme Profesional, Etika, Pengalaman, Dan Keahlian Audit Terhadap Ketepatan Pemberian Opini Oleh Auditor." Jurnal Akuntansi 1(3): 90-121.

Amalia, Dewi. 2017. "Faktor-Faktor Yang Mepengaruhi Kualitas Audit Intern." Jurnal akuntansi dan Bisnis 3(2): 156-66.

Ariyanto, Dodik. 2013. "Pengaruh Pemeriksaan Interim, Lingkup Audit, Dan Independensi Terhadap Pertimbangan Opini Auditor (Studi Kasus Pada Bpk Ri Perwakilan Provinsi Bali).": 1-14.

Aulia, Hilda Rizki, and Sigit Handoyo. 2015. "Auditor Dan Tingkat Materialitas." Optimum: Jurnal Ekonomi dan Pembangunan 5(2): 181.

Azlim, Darwanis, and Usman Abu Bakar. 2012. "Pengaruh Penerapan Good Governance Dan Standar Akuntansi Pemerintahan Terhadap Kualitas Informasi Keuangan SKPD Di Kota Banda Aceh." Jurnal Akuntansi 1(1): 1-14.

Badan Pemeriksa Keuangan Republik Indonesia. 2017. "Peraturan BPK RI Nomor 1 Tahun 2017 Tentang SPKN." http://jdih.bpk.go.id/wpcontent/uploads/2017/01/Peraturan -BPK-Nomor-1-Tahun-2017_filegabung.pdf.

BPKP. 2007. Filosofi Auditing. http://pusdiklatwas.bpkp.go.id/.

Fanny Surfeliya. 2013. "Professional Influence Skeptisisme, Competention, ,Audit Situation, Audit Ethics, Experience and Expertise Make an Audit of to Accuracy of Audit Opinion by Auditor BPK." Journal of Chemical Information and 
Modeling 53(9): 1689-99.

Febrianti, Irma. 2013. "Pengaruh Pengetahuan Terhadap Audit Judgement Dengan Kompleksitas Tugas Dan Independensi Sebagai Variabel Moderating (Studi Pada Akuntan Publik Di KAP Wilayah Sumatera)." Journal of Chemical Information and Modeling 53(9): 1689-99.

Hendriko, Pardede. 2015. "Pengaruh Profesional Judgement, Pengalaman, Keahlian, Pengetahuan Akuntansi Dan Audit Serta Skeptisme Auditor Terhadap Ketepatan Pemberian Opini Auditor." Akuntansi dan Manajemen 53(5): 1-116.

Ifany, Arfa, Unnisa. 2012. "Faktor-Faktor Yang Mempengaruhi Auditor Dalam Pemberian Opini Audit (Studi Pada Auditor Di BPK Perwakilan Provinsi Riau)." Journal of Chemical Information and Modeling 53(9): 1689-99.

Kusuma, M. 2012. "Pengaruh Akuntabilitas Terhadap Transparansi Penyusunan Laporan Keuangan Pemerintah Daerah (Studi Empiris Terhadap Persepsi Mahasiswa Diploma Akuntansi Di Kediri)." Skripsi 02(02): 02 No. 02.

Lili Suryani. 2017. "Pengaruh Skeptisme Profesional, Etika, Pengalaman, Dan Keahlian Audit Terhadap Ketepatan Pemberian Opini Oleh Auditor." Jurnal Akuntansi 1(3): $1-34$.

Mahaputra, Rama, and Putra Wayan. 2014. "Analisis Faktor-Faktor Yang Mempengaruhi Kualitas Informasi Laporan Keuangan Pemerintah Daerah." E-Jurnal Akuntansi 8(2): 230-44.

Medianto Suryo. 2016. "Sistem Informasi, Keuangan, Auditing Dan Perpajakan." Sistem Informasi, Keuangan, Auditing, Perpajakan.
P-ISSN 2541-1691 1(1): 49-56.

Menengah, Laboratorium Akuntansi, and Universitas Gunadarma. 2020. "Laboratorium Akuntansi Menengah Universitas Gunadarma PTA 2019/2020."

Menteri, Peraturan et al. 2006. "Peraturan Menteri Dalam Negeri Nomor 13 Tahun 2006." : 1-73.

Murti, Galuh Tresna Firmansyah, Iman. 2017. "Pengaruh Independensi Auditor Terhadap Kualitas Audit." (204): 9-18.

Najib, Ayu Dewi Riharna, Ariffudin, and Asri Usman. 2013a. "Pengaruh Keahlian, Independensi, Dan Etika Terhadap Kualitas Audit (Studi Pada Auditor Pemerintah Di BPKP Perwakilan Provinsi Sul-Sel)." (1): $1-26$.

2013b. "Pengaruh Keahlian, Independensi, Dan Etika Terhadap Kualitas Audit (Studi Pada Auditor Pemerintah Di BPKP Perwakilan Provinsi Sul-Sel) Effect of Expertise, Independence, and Ethics for Quality Audit." (1): 126.

Nurhasanah, Firmansyah, Kurnia Sari. 2018. "Pengaruh Pener Standar Akuntansi Pemerintanan, Pengendalian Internal Dan Kompetensi Sumber Daya Manusia Terhadap Kualitas Laporan Keuangan Pemerintah Provinsi Sumatera Selatan." Akuntanika 4(1): 1-17.

"Pengaruh Profesional Judgement, Pengalaman, Keahlian, Pengetahuan Akuntansi Dan Audit Serta Skeptisme Auditor Terhadap Ketetapan Pemberian Opini Auditor." 2015. 2(2).

PP No. 71 Tahun. 2010. "Peraturan Pemerintah Nomor 71 Tahun 2010." Arhiv za Higijenu Rada $i$ Toksikologiju 60(4): 982-92.

Praditaningrum, Anugrah Suci. 2015. "Analisis Faktor-Faktor Yang 
Berpengaruh Terhadap Audit Judgement." Accounting Analysis Journal 4(4).

Reza, Ferdiansyah. 2017. "Analisis Faktor-Faktor Yang Mempengaruhi Kualitas Hasil Pemeriksaan Audit Pemerintah ( Studi Empiris Pada BPKP Perwakilan Provinsi DKI Jakarta)." Jurnal Akuntansi dan Bisnis 3(2): 187-99.

Safrizal, Nanda, and Fauziah Aida Fitri. 2018. "Analisis Penerapan Standar Akuntansi

Pemerintah,Pengendalian Internal, Dan Kualitas Laporan Keuangan ( Studi Pada Skpd Bener Meriah )." Jurnal Akuntansi 3(1): 37-43.

Saputra, Yuda, and Nita Erika Ariani. 2018. "Pengaruh Kompleksitas, Kemandirian Dan Opini Terhadap Ketepatan Waktu Pelaporan Keuangan Pemerintah Daerah Di Indonesia." Jurnal Ilmiah Mahasiswa Ekonomi Akuntansi (JIMEKA) 3(4): 712-24. http://journal.uinjkt.ac.id/index.ph p/akuntabilitas.

Siagian, Rida MM. 2014. "Faktor- Faktor Yang Berpengaruh Terhadap Audit Judgment (Studi Empiris Pada Badan Pemeriksa Keuangan (BPK) RI Perwakilan Provinsi Riau)." Jurnal Akuntansi 2014(June): 1-2.

Siregar, Silky Raditya. 2012. "Faktor Faktor Yang Mempengaruhi Pertimbangan Opini Auditor Atas Laporan Keuangan Pemerintah Daerah Istimewa Yogyakarta." Accounting Analysis Journal 1(2).

SPAP PSA No. 2 Seksi 110. 2011. "Tanggung Jawab Dan Fungsi Auditor Independen." Ikatan Akuntan Indonesia (02): 3-4.

SPKN. 2017. "Standar Pemeriksaan Keuangan Negara (SPKN)." BPK Regulation No.1 2017: 107.

Sunarsih, Ni Made. 2014. "Analisis
Faktor-Faktor Yang Mempengaruhi Kualitas Audit (Studi Kasus Pada BPK - RI Perwakilan Provinsi Bali)." Jurnal Akuntansi (2013).

"UU RI No 15 Tahun 2004." : 1-25.

Vitalokasari, Silvia Arvianti, and Yustiana Djailani. "Pengaruh Gangguan Pribadi, Gangguan Ektern Dan Gangguan Organisasi Terhadap Independensi ( Studi Empiris Pada Bpk RI Perwakilan Provinsi Maluku Utara )." 6(2): 141-56.

Wahid, Hasyim. 2013. "Faktor-Faktor Yang Mempengaruhi $\mathrm{Au}$ Dalam Memberikan Opini t Atas Laporan Keuangan (Studi Pada BPK RI Perwakilan Provinsi ...." : 32-95.

Wulandari, Niken Ayu, and Sulardi Sulardi. 2018. "Pengaruh Karakteristik Daerah, Temuan, Dan Opini Audit (Studi Empiris Pada Website Pemda Di Indonesia)." Akuntansi Dewantara 2(1): 69-82.

Yunanti, Sri. 2016. “Analisis Opini Bpk Atas Laporan Keuangan Pemerintah Pusat." 5(1): 63-70. 